\title{
Does the ELP promote learning English as a foreign language at tertiary level?
}

\author{
Burcu Şentürk $^{a} *$ (D), İsmail Hakkı Mirici ${ }^{b}$ \\ a Bartın University, Bartın, 78100, Turkey \\ ${ }^{b}$ Near East University, Northern Cyprus, 99300, Nothern Cyprus
}

\section{APA Citation:}

Şentürk, B., \& Mirici, İ.H. (2019). Does the ELP Promote Learning English as a Foreign Language at Tertiary Level?. Journal of Language and Linguistic Studies, 15(2), 695-718.

Submission Date:.27/04/2019

Acceptance Date:.07/06/2019

\begin{abstract}
The study investigated the effect of European Language Portfolio (ELP) on students' attitudes towards learning English. The study also examined the attitudes of students and teachers towards the ELP and its implementation into the curriculum. The study was conducted at Bülent Ecevit University the School of Foreign Languages Basic English Department in the 2016-2017 academic year. The data collection instrument employed in this study was semi-structured interviews which were conducted with thirty students and five teachers.

The analysis of the interviews indicated that the ELP can promote self-assessment on the condition that it is used effectively both by the teachers and students and as a consequence the students support having more positive attitudes towards learning English. Additionally, it was found that the students felt positive towards the ELP and working with it as far as they used it correctly in their classes as part of the curriculum.

In addition, the findings of the study indicated that both the teachers and the students believed that the ELP was a tool for self-assessment; however, the implementation of the ELP in the curriculum of the School of Foreign Languages at Bülent Ecevit University needs support since the ELP has only been newly introduced in Turkey as well and the teachers have very little information about the use and effectiveness of the ELP in language learning. However, this study showed that the ELP could be used as a tool to promote self-assessment and to create learnercentered classrooms in Turkey.
\end{abstract}

(C) 2019 JLLS and the Authors - Published by JLLS.

Keywords: Self-assessment, European Language Portfolio (ELP), life-long foreign language learning, intercultural competence, the Common European Framework of Reference (CEFR), adult ELP

\section{Introduction}

It is widely believed that students' learning potential increases when their attitude towards language learning is positive and motivation runs high. The research into the connection between positive attitudes and successfully learning a second language supports this simple observation. Self-assessment is a key for autonomous language learning. It enables students to monitor their progress, relate learning to individual needs. Training students in self-assessment has gained increasing currency and has been investigated in a considerable number of studies.

\footnotetext{
* Corresponding author. Tel.: +090-378-501-1000

E-mail address: bsenturk@bartin.edu.tr
} 
The ELP is considered as an effective self-assessment tool. A number of researchers such as Glover, Mirici, and Aksu (2005) suggest that the ELP is a vehicle whereby learners can develop learner responsibility and autonomy by means of self-reflection and awareness. The Council of Europe (2006) also puts forward that the ELP is a tool to promote learner autonomy. Likewise, Glover, Mirici and Aksu (2005: p. 90) stress that the ELP encourages language learning through motivating learners; therefore, enabling them to empower positive attitudes through learning a language. There are some studies which suggest that the ELP promotes self-assessment; therefore, enable learners to have positive attitudes towards learning a language (e.g., Little and Perclova, 2001; Kohenen, 2001; Little, 2002b; Ushioda and Riley, 2002; Kohenen, 2004; Mirici, 2006; Ceylan, 2006; Koyuncu, 2006; Little, 2009). However, there is not a particular study which confirms the effect of the ELP on the students' attitudes towards learning English in English classes. In line with this background, the present study aims at investigating the effect of the European Language Portfolio on students' attitudes towards learning English as a foreign language.

\subsection{Literature review}

\subsubsection{Autonomy}

Holec (1981: 3) defines learner autonomy as the "ability to take charge of one's own learning", emphasizing that this ability "is not inborn but must be acquired either by 'natural' means or by formal learning". The first step towards developing the ability to take charge of one's own learning is when s/he accepts full responsibility for the learning process, knowing that success in learning depends mainly on himself/herself rather than on other people. This acceptance of responsibility entails the idea that people set out to learn, "in a systematic, deliberate way" (Holec, 1981: p.3), the skills of reflection and analysis that enable them to plan, monitor and evaluate their learning. Another point to be mentioned is that, not all learners may be ready for self-managing and self-regulating their own learning, which requires teachers to offer opportunities to help them develop some necessary strategies and metacognitive processes. Such kind of training on 'learning how to learn' can be developed through a sound dialogue between learners and the teacher (Doğan, 2015).

\subsubsection{Importance of Learner Autonomy in Language Learning}

The concept of "autonomy" has been the center of attention in language learning and teaching because it promotes situations where the learners' ability to learn is improved. Learning how to learn is a critical aspect that teachers must bear in mind to keep up with the conditions of the changing world. Since scholars have different perspectives on this matter, it is not easy to provide a simple answer to the question of why to promote learner autonomy in language classes.

Benson (2006) argues the need of learner autonomy in terms of the innovations that have become significant over the last thirty years. In the past three decades, a rising attention to learner autonomy, self-directed learning, learner centeredness, self-access systems and individualized learning is observed in SLA literature, which puts learner autonomy into a critical point in language learning settings.

Crabbe (1993) believes that autonomy has been recognized as a desired aim for three main reasons: the psychological, the practical, and the philosophical - 1) The psychological reason is that individuals can learn better when they are in charge of their own learning; learning is more purposeful and permanent when people take the responsibility. Besides, learners that are involved in decision making regarding their education would feel more motivated in their learning and would become effective learners; 2) Practicality. When the recent conditions and facilities of institutions are taken into consideration, it would be realistic to expect that a teacher may not continuously be available to help because of the number of students in classes and additionally, in the long run, learners will have several teachers in their lives. That is why, learners should be able to learn and follow their studies on their own; 
or learners might not have enough free time or finance to be a part of educational institutions; and last, Crabbe (1993) adds, a society might not provide the required facilities to every member in the area of learning and learners. Under these circumstances, learners should provide themselves with their own learning needs to obtain the knowledge and skills that they want; and 3) Philosophical. Crabbe (1993) states, people have the right to make their own choices freely not just in learning a language but also in all other areas.

According to Little (2000), there are two essential ideas behind making learners autonomous. Firstly, if individuals are occupied with their own learning, there is a greater possibility they will be more efficient and effective. Moreover, if an individual is more focused and individualized, what is given in educational contexts is possible to serve learners' wider agendas. Secondly, if learners are actively dedicated to their learning, issues surrounding motivation are strengthened. While one might not constantly feel completely positive regarding all features of their learning, he/she will have established the attitudinal and reflective resources to tackle short-term motivational setbacks.

Furthermore, Ellis and Sinclair (1989) highlight the importance and inspiration of learner autonomy in language classes. They claim that assisting learners who take on more responsibility for their own learning is helpful because they take charge of their own learning as they learn the things they are ready to learn. Further, the learners who are accountable for their own learning can continue learning outside the classes.

To conclude, individuals who are reflectively involved in planning, monitoring and evaluating their own learning should be highly successful since they are involved in their learning processes. Thus, individuals should use this "reflective engagement" (Little, 2000) in implementing the skills and knowledge of the language studied in and outside of the classes.

\subsubsection{The ELP as a Tool for Improving Autonomy}

A language learner having an ELP should do the following items which direct them to be inevitably an autonomous learner (Little, 2004):

- Know what their whole language skills are according to the common reference levels and reflect on the next targets of theirs in order to improve their learning.

- Give more importance to productive skills (such as, writing and speaking) (which many learners try to avoid) as they see that their improvement really makes sense in the future.

- Reflect on the learning styles that are suitable to them so they learn how to learn which makes their job and also their teachers' job easier. This may also help them learn other languages, which leads to plurilingualism objectives of the ELP.

- When they discover the transparency of the targets of ELP, they can clearly see how their learning improves so they are keener on being engaged in the activities especially in communicative ones.

As ELP helps the teacher to convert any communicative activity into a recorded task and plan for individuals and the whole class both in short term and long term, and use portfolio approach in the assessment criteria. Thus, the learners experience the process and the results of implementation of ELP and become more autonomous in the long run.

\subsubsection{Functions of the ELP}

The ELP has three pedagogical focuses. It is intended to foster the development of learner autonomy, promote intercultural awareness and intercultural competence, and encourage plurilingualism. And it has a reporting as well as a pedagogical function since it provides concrete evidence of language learning achievement that complements the grades awarded in tests and examinations. The Council of Europe developed the concept of a European Language Portfolio (ELP) in parallel with the Common European Framework of Reference for Languages (CEFR; Council of Europe 2001), and the ELP is linked to the CEFR by its "I can" checklists, which are derived from the descriptors in the CEFR's illustrative scales. 
The idea was that by supporting the development of learner autonomy, intercultural awareness and plurilingualism, the ELP would help to communicate the CEFR's ethos to language learners (Little, 2016).

Schneider and Lenz (2001: p. 3) describe pedagogic functions of the ELP as follows table 1.:

Table 2.3: Pedagogical Functions of the ELP (Schneider and Lenz, 2001, p. 3)

\begin{tabular}{|c|c|}
\hline The ELP; & \\
\hline \multirow[t]{3}{*}{$\begin{array}{l}\text { promotes motivation of learners so that they } \\
\text { can; }\end{array}$} & $\begin{array}{l}\text { Improve their communication competence in } \\
\text { various languages }\end{array}$ \\
\hline & learn additional languages \\
\hline & seek out new intercultural experiences \\
\hline \multirow[t]{3}{*}{$\begin{array}{l}\text { encourages and helps learners so that they } \\
\text { can; }\end{array}$} & $\begin{array}{l}\text { reflect upon goals, and ways of learning, and } \\
\text { accomplishments in language learning }\end{array}$ \\
\hline & plan their learning \\
\hline & learn in an autonomous way \\
\hline \multirow{3}{*}{$\begin{array}{l}\text { motivates learners to promote their } \\
\text { plurilingual and intercultural experience by } \\
\text { means of; }\end{array}$} & contacts and visits \\
\hline & reading \\
\hline & use of the media \\
\hline
\end{tabular}

\subsubsection{Practical Uses of ELP}

Many people have language skills that are not reflected in the qualifications or certificates they have gained. This may be because they have not been assessed or learned in formal education. At the same time, some basic foreign language skills may be sufficient to meet people, do shopping, or listen to a song...etc. The ELP enables the language user to see and evaluate what he/she can do in another language, and to record all the language skills gained and experiences with other cultures. Besides recording the current skills, the ELP helps to develop the skills through practice and experience. It helps the language user to become self-managing as he/she recognizes his/her strengths, weaknesses and plans for further progress. Also, he/she consciously or unconsciously reflects on learning styles and the one which suits him/her the most. For a job application, the ELP may be a part of the CV. Especially the Dossier section proves and illustrates what the applicant can do using another language.

Little and Perclová (2001) listed the learners' experiences reported by the teachers who worked with the ELP in the pilot study;

- "Motivation of all the learners, even the slower ones

- Increases their self-confidence when they have a list of their actual abilities

- Learners spend more time thinking about their language abilities and knowledge

- Voluntary work makes them more active

- Learners can develop their own language abilities

- Learners realize that they can extend their English language out of school as well Curriculum Innovation on the Basis of the European Language Portfolio"

The ELP is designed to:

- "encourage the lifelong learning of languages, to any level of proficiency 
- make the learning process more transparent and to develop the learner's ability to assess his/her own competence

- facilitate mobility within Europe by providing a clear profile of the owner's language skills

- contribute to mutual understanding within Europe by promoting plurilingualism (the ability to communicate in two or more languages) and intercultural learning" (Suter, 2002).

Briefly we can say that people of Europe are building a single Union out of many diverse nations, communities, cultures and language groups trying to exchange ideas and traditions people with different histories but a common future. So the ability to understand and communicate in other languages is a basic skill for all European citizens. ELP is a practical tool to reach this goal.

\subsubsection{Assumed Advantages of the ELP}

According to the feedback of the individual teachers in the pilot projects of the ELP, the ELP had positive effects on language learning. One teacher from the Czech Republic stated that ELP helped them to make their job easier: "I was helped by the portfolio's clear statement about the aims of teaching and the transparency of teaching and learning results. The descriptors encouraged me to reflect more deeply on my objectives as a teacher" (as cited in Little \& Perclova, 2001: p. 17).

In addition, not only learners but also teachers can make use of the ELP so that they can help the learners via the ELP. According to an ELP project in Finland, the ELP functioned both as a pedagogical tool for teachers to guide learning and as a practical device for students to take responsibility for their own learning process under the teacher's guidance and tutoring (Kohonen \& Westoff, 2003). Little and Perclova (2001) emphasizes also that achieving learner autonomy, self-knowledge and "a growing capacity for reflective thinking" are fundamental. These were some of the outcomes of the ELP reported by the teachers working with the ELP. According to these results of the projects, it is argued that the ELP can "develop learners' motivation, reflective capacities, and encourage them to take their own learning initiatives" (p.19). The ELP enables the learners increase their language awareness by the use of the 'can-do' statements, which help the learners to reflect on their language learning processes (Meister, 2005). The ELP can be a valuable tool for learners to learn a language and monitor their own learning process. Schneider (2006) summarizes various benefits of using the ELP. For example, the ELP is a record which shows both the products and processes the language learner goes through. It includes both self-assessment and teacher assessment. Moreover, it is not only for one specific level. The ELP is a document which can be used by the learners from one level to another. The ELP does not belong to the institution. The learners can keep it after formal education, as well; in other words, it is a tool used for lifelong learning (Schneider, 2006).

\subsection{Research question}

1. How can the ELP help learners to develop positive attitudes towards language learning?

\section{Method}

\subsection{Participants \& Setting}

The study was carried out at the Department of Basic English at Zonguldak Bülent Ecevit University, Turkey. The students study English for general purposes study English during a complete academic year before they start their university education at their departments. 225 A1 level students of English participated in the study. The students were all four-year undergraduate students. The medium of instruction at the university is English for the English Language Translation Department. At the 
beginning of the academic year, students took an English Proficiency Examination and the students getting 60 and higher grades on this exam started their education in their departments. The students whose English were not sufficient enough to pass this exam were divided into three levels (A1, A2, B1) according to the result of the placement test and start English Preparatory Education in groups of 15 to 20 students.

\subsection{Data Collection Instrument}

This study includes qualitative data. Qualitative data were gathered by means of semi-structured interview questions. The main instrument of the study is the ELP published by BEDAF (British Educational Affairs). 950 copies of the European Language Portfolio, purchased from a British website, www.bedaf.org.uk, were handed out to all students. After students used the ELP for the whole semester, semi-structured interviews were administered with 30 students using ELP and 5 instructors of these students.

They were interviewed individually about what kind of activities they did for the ELP and what they experienced.

The students were chosen randomly. Eclectic random sampling model was used. From the classes that participated in the study, the researcher checked the classroom lists and chose three students in each class randomly. When she chose a student who did not attend classes, she asked the instructor to choose another student and another student (a substitute student) was invited. All students were using the ELP.

The interviews with students were held in Turkish to make the students easily express their ideas about the ELP, and were held in a friendly atmosphere instead of asking one question after another. Hence, every interview with one student lasted approximately 15 minutes. The length of the interviews varied according to the experiences the students had with the ELP. All the interviews were recorded. The questions for the interviews were prepared beforehand using the topics in the 'ELP guide for teacher trainers' of Little and Perclova (2001) and in Little (2003) (see Appendix 7 \& 8). The interviews were beneficial for the students as well as the study because the interviews gave the students the opportunity to ask about the problems they had faced in using the ELP. The students described the activities they had done in detail, the benefits and the drawbacks of the ELP. These interviews provided information about and insight into the students' ELP use and self-assessment (for sample transcription, see Appendix9 \& 10).

Five responsible teachers were interviewed towards the end of the study. The interviews were held in English and recorded. The questions were prepared beforehand by considering the topics in the "ELP guide for teacher trainers" by Little and Perclova (2001), Little (2003) and similar to students' interview questions. The teachers were asked questions about the students use of the ELP in terms of motivation, consulting with them about problems, and their ideas about implementing the ELP in the curriculum of the school.

All the student and teacher interviews were transcribed right after they were done.

\subsection{Data Analysis}

Qualitative data was recorded and analyzed by transcribing the interviews. Content analysis was done and constant themes were found, thematic analysis was done. Transcripts were read by the researcher to categorize the data to put them into relevant groups for a better analysis. Inter-coder reliability was also checked. 


\section{Findings \& Results of Analysis}

\subsection{How can the ELP help learners to develop positive attitudes towards language learning?}

\subsubsection{Results of Student Interviews}

Interview results about what extent ELP can help learners develop positive attitudes towards language learning will be considered under these categories: 1) the sign of improvement, 2) implementation- filling in the ELP, 3) self-assessment, 4) benefits of the dossier part in the ELP, 5) problems related to the ELP. The findings from the interviews related to these six headings are presented below.

When students were asked what they liked most about the ELP, the most recurring theme was the sign of improvement.

\section{The sign of improvement}

The students were asked what they liked most about the ELP, and all of the students stated that by the help the ELP, they were able to see how much progress they had during the term. When they fill in the descriptors in the ELP for the first time at the beginning of each level, they gave low marks, but when they pass the level, they fill in the descriptors again with a different color and they see the improvement they had. They also had a small chat with their teachers about which points they improved, which were the same and how they can improve it. All students stated that it was really beneficial for them to see what they can do and how they improved themselves during the term. One student mentioned:

\footnotetext{
"We can see the difference; I mean the improvement. For example, I am not the same as I was at the beginning of the year, like going on to the next stage." (Student 1- A1 Level)
}

Another student also stated that:

"When we fill in it, it shows me how much I learnt English, in this way; it enables me to see the improvement I have during the year." (Student 2- A1 Level)

Another student also mentioned the same issue:

"From the beginning of the term, we filled in all the skills for our level, for example for some of the topics, I gave myself 1 or 2, but throughout the end of the year, we refilled it and I saw that I improved myself and gave high points for these topics. And also we collected a student portfolio." (Student 3A1 Level)

Another student also commented on this topic:

"From A1 level, I realized how much I progressed, which level I achieved." (Student 4-A1 Level)

\section{Implementation - Filling in the ELP}

The students were asked whether they experienced any difficulties in filling in the parts of the ELP for the first time, including understanding the descriptors and objectives of the ELP. When the ELP is filled for the first time, the students have to do some paper work. For each section, they write information about the language they are learning. For example, in the passport they write about their level. In the biography section, they write about how they have learned the language, and so forth. The reason for asking this question was to be sure that the students understood the parts of the ELP and how they were expected to work with it as it was also translated into Turkish. 
Most of the students did not experience any difficulty in completing the parts in the ELP. They said that it was clear for them, and they just followed the instructions given in the ELP. One student who was interviewed once had some difficulties, but the reason was that her teacher did not do any training session, just told them to fill it in at home; however, after we met once and worked together with the ELP, she understood what she was expected to do. Although some students attended the training session, they also stated that they did not like filling in the biography part as it frequently asks the same kind of questions related to their language learning experience. All students stated that they benefitted a lot from the activities they completed in the Dossier section. Especially process writing was very informative for them. They all commented that since ELP was translated in Turkish it was very easy to understand the 'can-do' statements in the ELP and they were able to work with the objectives and completed activities for their portfolios.

On the whole, most of the students did not face any difficulties while filling the ELP. This may be because of their proficiency level and of the instructions in the ELP. Also the one class hour introduction was useful for them. It was indicated that both the instructions in the ELP, and the training was clear for the students, so they did not experience any difficulty in filling in the portfolio.

One of the students commented to the second question of the interview which was asking whether they had any difficulty in filling in the parts of the ELP:

"No, there was nothing we could not understand, it was pretty good." (Student 1-A1 Level)

Another student also stated:

"No, not at all. It was very easy. (Student 2- A2 Level)

Another student also mentioned:

"It was really clear and easy to fill in. I did not have any difficulty in understanding it and filling it." (Student 3-A1 Level)

\section{Self-Assessment}

The use of the ELP includes choosing objectives, finding activities for achieving these objectives and self-assessment both for finding the proficiency level for the first time and evaluating the outcomes of activities. Since these are the features of the ELP, the researcher tried to learn the reactions of the students to these features separately as well, although she had explicitly asked whether they liked the ELP and the problems they had faced. The results revealed that the ELP might be used to promote selfdirected learning because the students stated that they studied English slightly more than before working with the ELP and that the self-assessment and the 'can-do' statements made their learning process clearer. However, there was a need for teacher support at the initial stages and training for selfassessment. It can be concluded that the students were quite pleased with choosing their own objectives; finding activities and self-assessment although they needed help of the teachers sometimes.

One of the students mentioned:

"I think it was beneficial for my language development because it enabled me to see my deficiencies and give an opportunity to improve it." (Student 1-A1 Level)

Another student indicated:

"Yes, I do. I realized how much I improved myself, and thus it enabled me to love English." (Student 2-A2 Level)

Another student made a similar comment:

"Throughout a year, we learnt something, and I had the chance to criticize myself, I was able to see my deficiencies with the help of ELP and I tried to compensate for it." (Student 3-A1 Level) 


\section{Benefits of the Dossier Part in the ELP}

The students were asked whether they liked the activities done related to the ELP and included in the dossier part. All students stated that they really benefitted from it. Students have to include several items for each skill in their portfolio and this portfolio is accepted as the dossier part of the ELP. They do several activities in the class and choose the ones they want. And at the end of each semester, they present three of the activities they choose. While they present their works, they also comment that both the ELP and the portfolio helped the students realize their success or just the opposite and try to recover it. Therefore, the process of collecting the assignments and the process of revising them were very beneficial for them. Since they did process writing for the writing assignments, the students got regular feedback on their writing and they corrected their mistskes and handed their second and final drafts to their teacher. They stated that, getting feedback and correcting their mistakes immediately was very beneficial for their language development. One of the students stated:

\footnotetext{
"This year, I think preparing a portfolio was the most beneficial thing for me and other students. Because I really put an effort to do my homework, my presentations perfectly and while trying to complete them in a perfect way, I learnt a lot; therefore, I really think that portfolio is very important and beneficial for us." (Student 1-A2 Level)
}

Another student also commented on the same issue:

"Yes, I do. For example, our teacher gives homework or a task, we do it and she gives feedback, we see our mistakes and correct them." (Student 2-B1 Level)

\section{Problems Related to the Implementation of the ELP}

There were three problems indicated by the students: lack of time, finding their level for the first time in self-assessment, and lack of teacher help. The results related to each category are presented below. When the learners suggested that the ELP could be implemented to the curriculum, they stated that it should be on volunteer basis because they thought that the ELP needs extra time, and they did not want to be forced to keep it at school. Therefore, the common problem of the students while working with the ELP was lack of time. The students have 26 class hours a week. They leave school at four in the. Besides the exams, for reading class they are asked to prepare extensive reading reports. They have quizzes four times a term. For writing class, they prepare portfolios with at least ten assignments, for which they prepare two drafts and one final draft, and they write journals. For speaking class, they are required to prepare projects, and for grammar they have quizzes and implicit grammar exams. All these have a value for their final grade.

One of the students said:

"The difficulty was related to me, I could not figure out what my level is, I could not decide objectively. I had difficulty in giving the points." (Student 1- A2 Level)

Three students thought that the ELP lacked regular teacher help. They needed help for finding out whether the activity they carried out was correct or incorrect in terms of language use and content. In fact, there is a special column in the 'can-do' statements for the teachers. One of the students commented:

\footnotetext{
"I think we should think from both the teacher's side and our side, and for me, it was not beneficial. I think we could not do it correctly, so we could not get benefit from it." (Student 2- A1 Level)
}

After the students find their level, or work for an objective, the teacher can take the ELP of those students and assess them as well to give the students the opportunity to compare their own view with the teachers. This result may indicate that students want teacher feedback on the activities they complete.

One of the students stated: 


\begin{abstract}
"For me it is unnecessary. I do not think that it has any contributions to us. I did not have difficulty in filling in the levels, but I had some difficulty in filling in the first part, I mean the language biography part. (Student 3- A1 Level)
\end{abstract}

To summarize, the students complained about having limited time for working with the ELP. They also needed teacher support and feedback for the activities and objectives, and said that there is too much to fill in when working with the ELP for the first time.

\title{
Did Students like the ELP?
}

During the interviews the students were also explicitly asked whether they liked the ELP, and what they most liked about it. The reactions of all the students were quite positive. All the students liked working with the ELP, and the things they liked about the ELP were choosing own objectives and selfassessment. Some students stated that they liked to work independently. They were happy about taking the responsibility to choose what kind of activities to do. Most students liked self-assessment. One of the student stated that she had gained more confidence in learning English while working with the ELP by the help of the self-assessment the ELP included. Her quotation is presented below:

"It is good to assess your own language learning and to prove myself in language learning...I became more confident in English.” (Student 1 - A1 Level)

One student who was interviewed stated that it was a good feeling not to take any grades after doing an activity. One student also reported that the ELP is a good opportunity to use when applying for a job. As a result, it was found that there was a strong positive attitude towards working with the ELP. The students were also asked whether they found the ELP beneficial for language learning. All students stated that it was.

One student interviewed once said that before using the ELP, he used to listen to songs but only the music, but now, he tries to catch and understand the words in a song. The sequence is shown below:

"The ELP made me gain new habits for example before the ELP I used to listen to foreign music but only the sound now whenever I listen to foreign music I try to understand the lyrics." (Student 1-A2 Level)

Another student said that she had worked on objectives, carried out some activities; during these she was improving herself in English. Another one claimed that she had learnt more vocabulary while working on the reading objectives in the ELP and could express herself better in writing in English. Therefore, the ELP was beneficial for seven of the students in terms of learning English, and two students stated that it was beneficial for the development of their personality in learning English.

To summarize the results for this category, it can be said that:

1. students felt positive towards the ELP.

2. students liked setting their own goals and assessing themselves.

3. they thought that the ELP was beneficial for language learning since they spent more time on English.

4. they gained more confidence with the self-assessment and the activities they carried out.

5. they liked to take responsibility for their learning.

However, the only negative side of the ELP was that it demanded time since the students considered it as an extra work.

Considering the data collected to find out what the students' opinions about the ELP were, it can be said that most of the students think that the ELP is useful for their language learning and gaining confidence in language learning although they felt the need for teacher support while working with the ELP, and they did not have much time for it. Furthermore, the last question in the interview was if the 
students recommend the use of the ELP in the prep school the following year, and all the students said: "Definitely yes!" which really summarize the whole research. When the researcher asked the students if they think using the ELP as an effective self-assessment tool, again, all the students said "Yes!"

In this section the results of the analyses of the interviews with the students were presented. The results were given in categories for the student interviews. Some of the categories were named in the light of the questions prepared beforehand, and some of them were found during the transcription process. This section tried to find out to what extent the students experienced self-directed learning via the ELP and what their reactions towards the ELP were. In the next section, results of the teacher interview will be presented as the other set of qualitative data supporting the data from the interviews.

\subsubsection{Results of Teacher Interviews}

In this section, results of the interviews with the teachers will be discussed. Five teachers were interviewed in order to get information about to what extent the ELP can help learners to develop positive attitudes towards language learning.

The results of the teacher interview support the data of the student interview presented in this section. This gives an opportunity to see the consistency between the ideas about the ELP of the students and the teachers, and it helped to get the opinions of the rest of the participant students related to the ELP.

\section{The sign of improvement}

The teachers were also asked what they liked most about the ELP, and what their students liked most about the ELP. The teachers stated that by the help the ELP, their students were able to see how much progress they had during the term. When they fill in the descriptors in the ELP for the first time at the beginning of each level, they gave low marks, but when they pass the level, they fill in the descriptors again with a different color and they see the improvement they had. The teachers stated that their students were very happy when they realize the improvement they had. They also had a small chat with their students about which points the students improved, which were the same and how they can improve it. All teachers stated that it was really beneficial for them to see what they can do and how they improved themselves during the term. One teacher mentioned:

"Students generally know something, but they are not aware of what they know, ELP is a concrete document for them to see it. They can realize which topics they have problems; which topics they feel well. Because of this fact, they like it very much." (Teacher 1-13 years experience)

Another teacher stated the same topic:

"I think the most important feature of the ELP is that it enables the students to be aware of their language development, feeling awareness, and then having the chance to evaluate themselves, I mean self-assessment, because of these reasons, students really like it, so do I. The students were able to see themselves, what they were able to do and what they couldn't do, how much they can do in each skill and their deficiencies and they tried to improve them, worked on them, and improved themselves." (Teacher 2-15 years experience)

\section{Implementation - Filling in the ELP}

The teachers were asked whether their students experienced any difficulties in filling in the parts of the ELP for the first time, including understanding the descriptors and objectives of the ELP. When the ELP is filled for the first time, the students have to do some paper work. For each section, they write information about the language they are learning. For example, in the passport they write about their level. In the biography section, they write about how they have learned the language, and so forth. The reason for asking this question was to be sure that the students understood the parts of the ELP and how they were expected to work with it as it was also translated into Turkish. 
The teachers stated that most of the students did not experience any difficulty in completing the parts in the ELP. They said that it was clear for them, and they just followed the instructions given in the ELP. One teacher who was teaching to B1 level stated that the students got bored when they filled in the same part for the second time. It may be because of their level, since their level is high; they generally gave high grades for each descriptor, so they may get bored to fill them again. However, she also mentioned that when she compares her students' experience with the previous year's students, she states that B1 level students benefitted more than the low level students. Since they are more aware of the learning process, the ELP helped them to be more aware and gave chance to them for self-assessment. Another teacher mentioned that they also did not like filling in the biography part as it frequently asks the same kind of questions related to their language learning experience. Furthermore, one of the teachers mentioned that some of the students had difficulty in self-assessment; they couldn't decide what grade to give to themselves for some of the descriptors. Moreover, the teachers also stated that students benefitted a lot from the activities they completed in the Dossier section. They all commented that since ELP was translated in Turkish it was very easy for the students to understand the 'can-do' statements in the ELP and they were able to work with the objectives and completed activities for their portfolios. The teachers also allotted a class hour to introduce the ELP to their students, and answered their questions about it.

On the whole, teachers indicated that most of the students did not face any difficulties while filling the ELP. This may be because of their proficiency level and of the instructions in the ELP. Also the one class hour introduction was useful for them. It was indicated that both the instructions in the ELP, and the training was clear for the students, so they did not experience any difficulty in filling in the portfolio.

\section{Self-Assessment}

The use of the ELP includes choosing objectives, finding activities for achieving these objectives and self-assessment both for finding the proficiency level for the first time and evaluating the outcomes of activities. Since these are the features of the ELP, the researcher tried to learn the reactions of the teachers to these features separately as well, although she had explicitly asked whether the students liked the ELP and the problems they had faced. The results revealed that the ELP might be used to promote self-directed learning because the teachers stated that the students studied English slightly more than before working with the ELP and that the self-assessment and the 'can-do' statements made their learning process clearer. However, there was a need for teacher support at the initial stages and training for self-assessment. It can be concluded that the students were quite pleased with choosing their own objectives; finding activities and assessing themselves although they needed help of the teachers sometimes. Furthermore, one of the teachers also commented that the ELP would be more beneficial for the higher level students since they are more eager to learn English and more aware of the process.

One of the teachers mentioned:

"I think the most important feature of the ELP is that it enables the students to be aware of their language development, feeling awareness, and then having the chance to evaluate themselves, I mean self-assessment, because of these reasons, students really like it, so do I. The students were able to see themselves, what they were able to do and what they couldn't do, how much they can do in each skill and their deficiencies and they tried to improve them, worked on them, and improved themselves." (Teacher 1-15 years experience)

Another teacher also commented on the same issue:

"Students generally know something, but they are not aware of what they know, ELP is a concrete document for them to see it. They can realize which topics they have problems, which topics they feel well. Because of this fact, they like it very much." (Teacher 2-15 years experience) 


\section{Teacher Impact}

One of the recurrent themes in the teacher interviews was the importance of the teacher. The teachers and also the students stated that if the teacher really believes in what s/he does, s/he can make her/his students believe in, too. For example, as the teachers and some of the students mentioned, the teachers who know the usefulness of the ELP described it well to her/his students, but the teachers who do not know the purpose and the use of the ELP skipped explaining it during the class hour and gave it as homework to students and since the students meet with the ELP for the first time, they cannot understand the need and the use of it and have a negative feeling and attitude towards using it. Actually, the ELP is a new tool for the instructors at Bülent Ecevit University the School of Foreign Languages the Department of Basic English. Therefore, even if the administration is trying to support their teachers to use it and learn about it, only few of them is eager to learn, but the traditional language teachers reject it as they mostly believe in the effectiveness of the traditional methods in language teaching methodology. As a result, since they do not know what the ELP is and do not try to learn anything about it, they do not tell it to their students. So, the students cannot be informed about it. One of the teacher commented on the same issue:

\footnotetext{
"Absolutely, even if the students who are not motivated to learn a language appreciated it. However, the 'teacher' is very important; the more he teacher gives importance, the more the students take it seriously." (Teacher 1-15 years experience).
}

\section{Did Teachers like the ELP?}

During the interviews the teachers were also explicitly asked whether they liked the ELP, whether their students liked the ELP and what they most liked about it. The reactions of all the teachers were quite positive. They stated that most of the students liked working with the ELP, and the things they liked about the ELP were choosing own objectives and self-assessment. Some students stated that they liked to work independently. The teachers were happy that their students like taking the responsibility to choose what kind of activities to do. Most students liked self-assessment. They indicated that their students had gained more confidence in learning English while working with the ELP by the help of the self-assessment the ELP included. When the teachers were asked whether they found the ELP beneficial for language learning, all teachers stated that it was.

To summarize the results for this category, it can be said that:

1. teachers also felt positive towards the ELP.

2. they also state that students liked setting their own goals and assessing themselves.

3. they thought that the ELP was beneficial for language learning since they spent more time on English.

4. their students gained more confidence with the self-assessment and the activities they carried out.

5. the students liked to take responsibility for their learning.

6. teacher impact is really important.

Considering the data collected to find out what the teachers' opinions about the ELP were, it can be said that most of the teachers think that the ELP is useful for language learning and gaining confidence in language learning although they felt the need for knowledgeable teachers while working with the ELP. Furthermore, the last question in the interview was if the teachers recommend the use of the ELP in the prep school the following year, and all the teachers think that the ELP is an effective selfassessment tool and it should be used in the following years.

In this section the results of the analyses of the interviews with the teachers were presented. The results were given in categories for the teacher interviews. Some of the categories were named in the 
light of the questions prepared beforehand, and some of them were found during the transcription process. This section tried to find out if the teachers think the ELP is an effective self-assessment tool for their students and what their reactions towards the ELP were.

\section{Discussion and Conclusion}

\subsection{Discussion on the Reactions of the Students related to ELP}

The findings from the interviews revealed that most of the students felt positive about working with the ELP. It was found that the students believed that the ELP was a significant tool for language learning. Furthermore, since the objectives for learning language are clearly stated in the ELP, the students became more aware of their own learning. Therefore, they had more positive attitudes towards learning English after they used the ELP. This result is in line with that of Karagöl (2008) that she stated selfassessment checklists and learners' taking active role in choosing their tasks fostered their autonomy and this in turn raised positive attitudes towards learning a language.

Most of the students also had positive ideas about taking responsibility for their own learning. They reported that until this age, other people were always responsible for their learning, but the ELP encouraged them to take responsibility. Hence, they became more aware of their language learning processes. This result is in line with that of Glover, Mirici and Aksu (2005). They stated that their result showed a positive attitude toward the ELP and most of the students reported that they became more interested in their own learning with the help of the ELP. They also propose that the teachers agreed that the ELP contributed to the motivation of the students and that the attendance in the ELP user class remained high to the end of the year.

The interview results also revealed that most of the students wanted to continue to keep the ELP after the study as well and also recommend the use of the ELP in the following years at preparatory school. This finding also indicates that the students had positive attitudes towards the ELP otherwise they would not have wanted to continue working with the ELP and recommend the use of it. Meister (2005) also emphasizes that the ELP helps the learners raise consciousness about their language learning process. Also, in the affective view in this study, self-awareness of the students increased to some extent, and they reacted positively towards the ELP. This result also supports that of güneyli and Demirel (2006). They report that after a month's implementation of the ELP, learners reported having positive attitudes towards using the ELP in learning Turkish as a foreign language since they have been given the chance to monitor their own learning process and assess themselves.

The majority of the respondents stated that there is a considerable need to discover the knowledge which is especially useful in finding answers to the language problems. In this sense, it is important to lay stress on the importance of collaborating with the teacher. This can be explained with what Benson (1996, cited in Nordlund, 1997) says. According to him, taking charge of one's learning process, discovering knowledge, using learning resources appropriately or organization of the study environment can not only be accomplished by the student himself in accordance with his/her own options. There is a considerable need to make decisions by collaborating with the teacher. The respondents of the present study, thus, confirmed what Benson says. This finding supports Koyuncu (2006) since he states students liked working with the ELP and thought that the studying process for the ELP was helpful. Majority of the students participated in his study thought that the ELP showed them what they do in English and that the "can do" parts made them aware of their improvement in language process.

As regards self-assessment practices, it was evident that learners benefited from the self-assessment sessions; since they mostly referred to the ELP as a tool for them to evaluate them and see their progress. 
While assessing themselves, they could remember most of the descriptors from the lessons; so they did not have much difficulty understanding and reflecting on them. As Little (1999b) states, students can have an idea of what they can do with the language in concrete situations and tasks; so the "can do" statements can help them understand and assess what they can do with their language in specific contexts. . This finding is in line with Demirel (2003) in that he also suggests that the ELP contributed to the language learning and teaching process positively since their students gained more responsibility and ability to assess themselves. This result also supports that of Egel (2003). In his study, it was found that the ELP was an influential tool in promoting learner autonomy of the students in the experimental group, especially in the state school. Although self-assessment practices were not carried out much after the activities or lessons, one self-assessment session at the end of the term was even valuable for students to understand their standing in the language learning process. However, only one self-assessment session at the end of the term is obviously is not enough for students to judge their own success objectively and discover their strengths and weaknesses to plan their learning accordingly.

If the ELP was used systematically to allow learners to get involved in the language learning process by planning, implementing, monitoring and evaluating their learning, it would not only have a reporting function in which students only record their achievements on the checklists. Although reporting is also a function of the ELP, the pilot projects (1998-2000) were mostly concerned with developing its pedagogical function (Scharer, 2001). As Little (2006) also points out the ELP does not mean much to learners unless it plays an active role in the learning process. He adds that without a strongly developed pedagogical function, students may not find much outcome to record on the checklists at the end of a term. Little (2009b) also puts forward that the ELP is a way to provide learners with various language learning activities. However, if students attempt to record their progress as well as the outcome of their learning, then the pedagogical function of the ELP can be made use of. In the current research, too, learners got involved in the language learning process by becoming more aware of the language learning process and developing capacity for reflection and self-assessment and thus this enabled them to take more control of their own learning, which shows that not only the reporting but also the pedagogical function of the ELP was used. However, it could foster more autonomy if the reflections and assessments were carried out more regularly and used as a springboard for further goal-setting.

The findings suggested that students needed to be given more control and responsibility in the learning process. This point was also highlighted in the literature (Bouchard, 2009; Reinders 2000). If they were given more responsibility and control, they felt more connected with learning processes and got more involved in the process. If their ideas or suggestions were valued and taken into consideration from the beginning to the end of the study, their autonomy level might probably increase. This does not mean that teachers should leave everything to the control of students but negotiation or collaboration is necessary. Here as Little (2009) pointed out, interdependency rather than dependency was required. This perspective was also confirmed by Harkin et al. (2001) who argued that teachers should stand away from being authority figure so as to encourage learner autonomy. In his study, Chan (2003) also concluded that students should be avail of opportunities for more negotiation and decision-making. Bayat (2011) also confirmed that if students were given opportunity to learn in autonomous learning settings, Turkish students learning English as a foreign language might be autonomous learners.

\subsection{Discussion on the Reactions of the Teachers towards the ELP}

The findings from the interview with the teachers indicated that the teachers believed that the ELP was a useful tool to develop learner autonomy but implementing it in the School of Foreign Languages at Bülent Ecevit University might cause some problems because according to the general student profile, the students do not tend to take responsibility for their own learning unless they get a grade or so forth 
in the end. Also, the teacher factor is very important, not all the teachers implemented it in a proper way; as a result, some students could not benefit from using it.

The teachers agreed that with the use of the ELP, the students should be trained about self-assessment and choosing objectives. Furthermore, since they were introduced with the ELP for the first time and had limited information about it, they think that all teachers should get enough information about it and believe in the effectiveness of using it as a self-assessment tool. The doubts of the teachers towards the ELP can be considered normal since it is a new instrument for them as well.

The results of the study showed that teachers reported positive attitudes towards the use of the ELP in the class and they stated that the ELP made them become more aware of the language learning process, clarify their objectives, produce materials with their own preferences and evaluate their own learning. These results are in accordance with the results of the pilot studies 1998-2001 (Scharer, 2001), other reports of the implementation from 2001 to 2008

(Scharer, 2004;2008), some published research studies in Europe like Ushioda and Ridley (2002), Sisamakis (2006), Kohonen (2000) and the research carried out in Turkey concerning the implementation of the ELP and autonomy (Demirel (2003), Egel (2003), Glover, Mirici and Aksu (2005), Koyuncu (2006), Ceylan (2006), Güneyli and Demirel (2006), Karagöl (2008), and Yüce (2019). As Egel (2003) states in her research on the role of the ELP on learner autonomy in primary school children, the ELP is an innovation for language learning since it both provides a positive experience for primary school children and helps them in developing learner autonomy. Sisamakis (2006) also states that students developed considerably in terms of their autonomous behavior and reflective skills in language learning and that became more objective in their self-assessments. Little (2009b) also supports these views stating that the ELP helps students organize their learning, make a record of their learning and empower them to take responsibility for their learning.

To sum up, based on all the feedback received from the participants through interviews, it can be concluded that learner autonomy is fostered through the use of the ELP on a crucial level. Also, it can be concluded that the ELP:

1. is a source of self-assessment, it enables learners to be aware of their learning objectives, their strengths and weakneses. Having assessed their own language proficiency levels by means of the selfassessment part, the participants were able to find out what they were missing in terms of language competences and they were able to study in accordance with their needs as well as their weaknesses, which fostered motivation and learner autonomy.

2. enables its users to plan their study based on their weakenesse and to set learning objectives, hence promoting learner autonmy. The ELP helped the learners set their learning goals taking their weaknesses into consideration.

3. fosters learner autonomy by increasing self-confidence and self-awareness of its users regarding what they are/are not capable of in their target language. The students stated that their self-confidence and self-awareness soared through the ELP, especially with the help of checklists provided for each skill and proficiency level, which also promoted positive attitudes towards learning language.

4. makes its users more active participants of their own learning. Seeing their weaknesses and needs in language enabled the learners to make a study plan, the materials, the pace, the study times, the resources, and the task types of whch were determined by the participants based on their individual learning styles, learning pace, and so forth.

5. is a source that enables leaners gain more positive attitudes towards learning a language. 
6. is a source of learner autonomy since it enables its users to become more autonomous in the process of language learning.

7. enables its users to record and keep track of their language progress and process through cando stataements included in the checklists, and language dossier, which, as a consequence, motivates and promotes learner autonomy at the same time.

8. facilitates the language learning process by allowing its users to monitor their own language process, which, in return, facilitates learning since larners get to know where they stand in their learning process.

9. draws a framework as to what needs to be done to be proficient nough in a given skill and level, thus fostering learning autonomy. By means of the descriptors, the ELP allows learners to figure out what they are supposed to do do as to be competent in each language skill whether it is reading, writing, listening, spoken production or spoken interaction. Seeing the framework of what they need to accomplish in a given skill enables learners to be more autonomous.

To sum up, the ELP is recommended for implementation in the curriculum at the School of Foreign Languages at Bülent Ecevit University. However, implementing it in the curriculum needs support both from the teachers and students since they already have excessive workload, and the ELP will be added to this workload both of the teachers and students. They should not perceive the ELP as a burden. Furthermore, even if they agree to work with the ELP, both the teachers and the students need an effective training on how to work with the ELP and how to make the best use of it in the language learning process. Since there are not many studies and pilot projects on the ELP other than the ones of the Ministry of Education which do not include universities, more studies should be conducted to see how the ELP works in Turkey and at Turkish universities.

One of the major limitations of the study was not being able to implement the ELP in class level. Since the students at the School of Foreign Languages should be given the same instruction because of the same final exam they are going to take, it could be unfair to the students to use the ELP in class level. If the ELP was implemented in class level, the lesson time of the students would be taken, so they would be left behind the syllabus, and this would be unfair for the student participants. Therefore, the students could be introduced to the ELP for only two hours in class which was not enough to cover all the issues in the ELP in depth. Furthermore, since all the teachers at Bülent Ecevit university do not know much about the ELP as it is a new tool for the traditional language teachers, they could not implement it effectively at classes. Even, some teachers gave it as homework without talking about anything about it. Therefore, the students of these teachers did not have a chance to learn about the ELP, and so use it effectively. On the other hand, if the ELP could have been implemented effectively in class level by all instructors, it would have been used more effectively both by the teachers and students.

Another limitation was that more students could be interviewed regularly every week during the study so that more data could be collected in terms of the usefulness of the ELP for self-assessment.

The last limitation was that the ELP is part of the curriculum at Bülent Ecevit University; therefore, for students to have the equal chances for education, all students had the ELP, so there was not a seperate group who did not use the ELP. As a result, the difference in the attitudes of the students who had the ELP and who did not have the ELP is unknown.

\section{Suggestions for Further Studies}

In further studies which aim to highlight the significance of the ELP and toher self-assessment tools like learner style inventory and unit based checklists in terms of promoting self-assessment, the ELP 
could be implemented at class level to see to what extent it is effective for both self-assessment and language learning. Furthermore, other self-assessment tools can be promoted and studied. Additionally, in this study, some of the teachers also used the unt based checklists to assess their students, another study can compare the effectiveness of using the unit based checklists for students and teachers, how it affects students' attitudes towards learning language and their success. If interviews are going to be held, more student participants could be interviewed for more data about self-assessment and also more teachers can be interviewed. Also, student diaries can also be used to get more information about students. Another study could be conducted on the descriptors and objectives stated in the ELP. How the students interpret them, whether they use them effectively, and whether they can assess themselves with the help of the 'can-do' statements appropriately could be researched, perhaps by including teacher assessment as well and comparing the both of the assessments about the ELP. Additionally, this study did not focus on the effect of the ELP on individual skills such as reading, listening, speaking and writing. Therefore, another study can be conducted on the effects of the ELP on individual skills. Moreover, a study could be conducted on whether the ELP has an effect on developing self-confidence. Little and Perclova (2001) proposes that the ELP develops learners' self-confidence. Also, since some students in the study indicated that they became more confident about learning language by the help of the ELP, this can be also included in the scope of further research. Another study could be conducted on teachers about their general views on the ELP. In such a study it would be necessary that some introductory and training sessions may be given and group discussions about implementing the ELP in the curriculum of the school to be held. Future research may also focus on how the teachers make use of the ELP in terms of teaching and understanding the students' learning process. Last but not least, another study might be conducted to measure if the teachers are willing to use the ELP in their classrooms.

\section{Acknowledgements}

This research is based on a PhD thesis entitled "The Effect of Different Self-Assessment Tools On Students' Attitudes Towards Learning English" submitted to Hacettepe University Graduate School of Social Sciences in 2017.

\section{Endnote}

This study was partly presented at GlobELT 2019: 5th International Conference on Teaching and Learning English as an Additional Language, which was held in Kyrenia, Cyprus between the dates of April 11-14, 2019.

\section{References}

Balçıkanlı, C. (2010). Learner autonomy in language learning: Student teachers' beliefs. Australian Journal of Teacher Education, 35(1), 90-103.

Baylan, S. (2007). University Students' and Their Teachers' Perceptions and Expectations of Learner Autonomy in EFL Prep Classes (Unpublished Masters Thesis). Pamukkale University,Turkey.

Bem, D.J., (1970). Beliefs. Attitudes, and Human Affairs, Belmont, CA: Brooks/Cole

Benson, P. (2001). Teaching and researching autonomy in language learning. London: Longman

Benson, P. (2007). Autonomy in language teaching and learning. Language teaching, 40(01), 21-40. 
Benson, P. (2006). Learner autonomy 8: Insider perspectives on autonomy in language teaching and learning. Dublin: Authentik.

Benson, P. (2010). Teacher education and teacher autonomy: Creating spaces for experimentation in secondary school English language teaching. Language Teaching Research, 14(3), 259-275.

Benson, P., \& Voller, P. A. (1997). Independence in Language Learning. London, UK: Longman.

Black, P., Harrison, C., Lee, C., Marshall, B., \& William, D. (2003). Assessment for Learning: Putting it into Practice. Berkshire, England: Open University Press.

Borg, S., \& Al-Busaidi, S. (2012). Learner autonomy: English language teachers' beliefs and practices. ELT Journal, 12(7), 1-45.

Boud, D. (1995). Enhancing learning through self-assessment. London: Kogan Page

Boud, D., \& Falchikov, N. (2006). Aligning assessment with long-term learning. Assessment \& Evaluation in Higher Education, 31(4), 399-413.

Brajcich, J. (2000). Encouraging learner autonomy in your classes. The Language Teacher Online. Retrieved January 2, 2014 from http://jalt publications.org/old_tlt/articles/2000/03/brajcich

Breen, M. P., \& Mann, S. (1997). Shooting arrows at the sun: Perspectives on a pedagogy for autonomy. In P. Benson \& P. Voller (Eds.), Autonomy and independence in language learning (pp. 132-149). London: Longman

Carreira, J. M. (2005). New Framework of Intrinsic/Extrinsic \& Integrative/Instrumental Motivation in Second Language Acquisition. The Keiai Journal of International Studies, 76, 39-64.

Ceylan, M. (2006). European language portfolio as a self-directed learning tool. Unpublished Master's Thesis. Bilkent University, Ankara.

Chan, V. (2001). Readiness for learner autonomy: What do our learners tell us? Teaching in higher education, 6(4),505-518.

Cotterall, S. M. (2000). Promoting Learner Autonomy through the Curriculum: Principles for Designing Language Courses. ELT Journal. Vol. 54 No. 2 Retrieved January 6 2014, from http://eltj.oxfordjournals.org/content/54/2/109.full.pdf+html

Council of Europe, (1992). Transparency and coherence in language learning in Europe: Objecives, evaluation, certification. Report on the Rüschlikon Symposium. Strasbourg: Council of Europe.

Council of Europe, (1997a). European Language Portfolio: proposals for development. With contributions by I. Christ, F. Debyser, A. Dobson, R. Schärer, G. Schneider/B. North \& J. Trim. Strasbourg: Council of Europe.

Council of Europe, (1997b). Language learning for European citizenship. Final report (1989-96). Strasbourg: Council of Europe.

Council of Europe (2000). European language portfolio (ELP): Principles and guidelines, Document 
DGIV/EDU/LANG, (2000) 33, Strasbourg, Council of Europe

Council of Europe (2001). Common European Framework of References for Languages: Learning, teaching, assessment. Cambridge: Cambridge University Press.

Council of Europe (2004). European Language Portfolio Principles and Guidelines, with added explanatory notes. Strasbourg: Council of Europe.

Council of Europe (2006). European Language Portfolio: Key reference documents. Language Policy Division, Strasbourg. (Online: http://archive.ecml. At/mtp2/elp tt/results/DM layout/Reference\%20Materials/English/ELP\%20key\% 20reference \%20documents.pdf Retrieved on 28 November 2015).

Demirel, Ö. (2003). Implications of the European Language Portfolio Project in Turkey. Paper presented at the international symposium titled Common European Framework and Foreign Language Education in Turkey at Uludağ University, Bursa, 17-19 September, 2003.

Demirel, Ö. (2005). Avrupa Konseyi Dil Projesi ve Türkiye Uygulamaları. Milli Egitim Ü̧̧ Aylık Egitim ve Sosyal Bilimler Dergisi. Yaz 2005, yl 33, sayı 167. (Online) Retrieved 21 October 2009 from http://yayim.meb.gov.tr/dergiler/167/orta3-demirel.htm

Demirel, Ö. \& Mirici, İ. H. (2002). Yabancı dil eğitiminde öğrenen özerkliği. Milli Eğitim Dergisi, 155-156, 76-88.

Gagliano, K. - Swiatek, L. (1999). Improving Student Assessment Through the Implementation of Portfolios in Language Arts, Master's Action Research Project, Saint Xavier University, http//www.epnet.com/ehost

Gardner, R. C. \& Lambert, W. E. (1972). Attitudes and motivation in second language learning. Rowley, MA: Newbury House.

Gardner, R. C. (1982). Language attitudes and language learning. In E. Bouchard Ryan \& H. Giles, Attitudes towards language variation 132-14. Edward Arnold.

Glover, P., Mirici, İ. H., \& Aksu, M. B. (2005). Preparing for the European Language Portfolio: Internet connections. Turkish Online Journal of Distance Education- TOJDE, 6(1), [Online: http://tojde.anadolu.edu.tr/yonetim/icerik/ makaleler/179-published.pdf Retrieved on 02 January 2016]

Goullier, F., (2010). The most frequent errors to be avoided when developing a new ELP model. Strasbourg: Council of Europe.

Gonzalez, J. A. (2009). Promoting student autonomy through the use of the European Language Portfolio. ELT Journal Advanced Access, 63(4), 373-382.

Holec, H., (1979). Autonomy and foreign language learning. Strasbourg: Council of Europe

Holec, H., (1981). Autonomy and foreign language learning. Oxford: Pergamon. (First published 1979, Strasbourg: Council of Europe)

Holec, H. \& Huttunen I. (1998). Learner autonomy in modern languages. Education Committee: 
Council of Europe.

Kohonen, V. (2001). Developing the European language portfolio as a pedagogical tool for advancing student autonomy. In, L. Karlsson, F. Kjisik \& J. Nordlund (Eds.), All together now. Papers from the Nordic conference on autonomous language learning (pp.20-44). Helsinki: University of Helsinki Language Centre.

Kohonen, V. \& Westhoff, G. (2003). Enhancing the pedagogical aspects of the European Language Portfolio (ELP). Strasbourg: Council of Europe. Retrieved on 17th October 2005 from http://culture2.coe.int/ portfolio/ documents/studies_kohonen_westhoff.doc 17/10/2005

Koyuncu, S. (2006). The effect of the European language portfolio on learner autonomy for young learners (Unpublished master's thesis). Çukurova University, Turkey.

Köse, N. (2006). Effects of portfolio implementation and assessment on critical reading and learner autonomy of ELT students. Unpublished doctoral dissertation, Çukurova University, Adana.

Kristmanson, P., Lafargue, C., and Culligan, K. (2013). Experiences with autonomy: Learners' voices on language learning. The Canadian Modern Language Review, 69(4), 462-486.

Lambeir, B. (2005). Education as liberation: The politics and techniques of lifelong learning. Educational Philosophy and Theory, 37(3), 349-355

Lenz, P. \& G. Schneider, (2000). European Language Portfolio: guide for developers. Strasbourg: Council of Europe.

Little, D. (1991). Learner autonomy 1: Definitions, issues and problems. Dublin: Authentik.

Little, D. (1995). Learning as dialogue: The dependence of learner autonomy on teacher autonomy. System, 23(2), 175-182.

Little, D. (2009) The European Language Portfolio: where pedagogy and assessment meet (documentation for the ELP Seminar, Graz, 2009)

Little, D. (1999). Learner autonomy 1: Definitions, issues and problems. Dublin: Authentik.

Little, D. (2000). Why focus on learning rather than teaching? In D. Little, et al. (Eds.) Focus on learning rather than teaching: Why and how? (pp. 3-17). Dublin: Trinity College, Centre for Language and Communication Studies.

Little, D. (2002a). The European Language Portfolio: structure, origins, implementation and challenges. Language Teaching, 35/3, 182-189.

Little, D. (2002b). The European Language Portfolio, Turin Report (pp. 4). (document: DGIV/EDU/LANG (2002)17). Retrieved on 5th October 2005, from http://www.tcd.ie.

Little, D. (2004). Learner autonomy, Teacher autonomy and the European Language Portfolio. Dublin. Retrieved on 12th October 2005, from http://www.utc.fr.

Little, D. \& Dam, L. (2005). Learner autonomy: what and why? Unpublished doctoral dissertation. Retrieved 7 Sep, 2005 from http://jaltpublications. org/tlt/files/98/oct/littledam.html. 
Little, D \& Perclova R. (2001). The European Language Portfolio: A guide for teachers and teacher trainers. Strasbourg: Council of Europe. Retrieved on 4th October 2005, from http://culture2.coe.int/portfolio//documents/ELPguide_teachertrainers.pdf.

Little, D. \& Simpson, B. (2003). European Language Portfolio, the intercultural component and learning how to learn. (document: DGIV/EDU/LANG (2003)4) Retrieved on 10th October 2005, from http://www.tcd.ie.

Little, D. \& R. Perclová (2000). The European Language Portfolio: a guide for teachers and teacher trainers. Strasbourg: Council of Europe.

Little, D. \& L. King (2014). Talking with John Trim (1924-2013), Part II: Three decades of work for the Council of Europe. Language Teaching 47.1, 118-132.

Little, D. (2005). The Common European Framework and the European Language Portfolio: involving learners and their judgments in the assessment process. Language Testing, 22 (3): 321-336.

Little, D. (2010). What does it mean to "implement" the CEFR? Réflexions, 29(2), 20-21.

Little, D. (2012). The European Language Portfolio: History, key concerns, future prospects. In B. Kühn and M. L. Pérez Cavana (Eds.), Perspectives from the European Language Portfolio: Learner autonomy and self-assessment (pp. 22-42). New York, NY: Routledge.

Meister, M. E. (2005). The influence of the world of Council of Europe on language teaching in Austria. Retrieved on 11th February 2006, from http://www.ecml.at.

Mineishi, M. (2010). East Asian EFL learners' autonomous learning, learner perception on autonomy and portfolio development: In the case of educational contexts in Japan. 3(17) 1-8.

Mirici, I. H. (2000). European Language Portfolio: A tool for a common language education policy in Europe. Journal of Interdisciplinary Education, 6(1): 161-166.

Mirici, İ. H. (2006). Electronic In-Service Teacher-Training for the New National EFL Curriculum in Turkey. Turkish Online Journal of Distance Education, 7(1), 155-164. [Online: http://tojde.anadolu.edu.tr/yonetim/icerik/makaleler/244-published.pdf Retrieved on 03 January 2016]

Mirici, İ. H. (2008). Development and validation process of a European language portfolio model for young learners. Turkish Online Journal of Distance Education, 9(2), 26-34. [Online: http://tojde.anadolu.edu.tr/yonetim/icerik/makaleler/399-published.pdf Retrieved on 03 January 2016]

Mirici, İ. H. (2014). The Common European Framework of Reference for Languages (CEFR) and the European Language Portfolio (ELP) in S. Çelik (Ed.)

Newby D., Allan R., Fener A.B., Jones B., Komorowska H.\& Kristine Soghikyan K.(2007). The European Portfolio for student teachers of languages. [Çevrim-içi: http://archive.ecml.at/mtp2/fte/pdf/C3_Epostl_E.pdf], Erişim tarihi: 22.06.2014

Newby, D. (2012). Insights into the European Portfolio for student teachers of languages (EPOSTL) 
Cambridge: Cambridge Scholars Publishing.

Schärer, R., (2000). European Language Portfolio Pilot Project Phase, 1998-2000: Final report.

Strasbourg: Council of Europe. Available at https://rm.coe.int/CoERMPublicCommonSearchServices/DisplayDCTMContent?doc umentId=09000016804586bb (accessed 29 June 2016).

Schärer, R. (2002). The European Language Portfolio, Turin Report (pp. 13-14). (document: DGIV/EDU/LANG (2002)17). Retrieved on 5th October 2005, from http://www.tcd.ie.

Scharer, R. (2007) European Language Portfolio: Interim Report (2006). Language Policy Division Strasbourg, DGIV/EDU/LANG. (2007) 1 Review. Council of Europe. Retrieved on 1fifth October 2009 from www.coe.int/portfolio

Schneider, G.; Lenz, P. (2001). European language Portfolio: Guide for Developers. Strasbourg: Council of Europe, Modern Languages Division.

Schneider, G. \& Lenz, P. (2003). European Language Portfolio: Guide for developers. Retrieved on 13th October 2005, from http://www.culture2.coe.int/ portfolio//documents_intro/Eguide.pdf.

Stoicheva, M., G. Hughes \& H. Speitz (2009). The European Language Portfolio: an impact study. Strasbourg: Council of Europe.

Thanasoulas, D. (2000). 'What is learner autonomy and how can it be fostered?' The Internet TESL Journal, 11 .

Trim, J. L. M. (1978). Some possible lines of development of an overall structure for a European unit/credit scheme for foreign language learning by adults. Strasbourg: Council of Europe.

Udosen, A. E. (2014). Learner autonomy and curriculum delivery in higher education: The case of university of Uyo, Nigeria. International Education Studies, 7(3), 4050.

Ushioda E. (1996). Learner autonomy 5: The role of motivation. Dublin: Authentik.

Ushioda, E. and J. Ridley (2002). Working with the European Language Portfolio in Irish postprimary schools: report of an evaluation project. Dublin: Trinity College, Centre for Language and Communication Studies, occasional paper no. 61.

Victori, M. (Ed.). (2000). Autonomy in second language learning. Special issue of Links and Letters, 7. Universitat Autonoma de Barcelona. Servei de publicacions.

Yang, Nae D. (2003). Integrating Portfolios into Learning Strategy-Based Instruction for EFL College Students, International Review of Applied Linguistics

Yang, J. S. R. (2008). Motivational orientation and selected learner variables in East Asian Language Learners in the United States. Foreign Language Annals, 36(1), 44-56.

Yıldırım, Ö. (2012). A study on a group of Indian English as a second language learners' perceptions of autonomous learning, Anadolu University, İstanbul.3(2)1-12.

Yllmaz, S. (2010). Exploring Learner Autonomy Through the European Language Portfolio (ELP) in Turkish Context (Unpublished master's thesis). Boğaziçi University, Turkey. 
Yumuk, A. (2002). Letting go of control to the learners: The role of the internet in promoting a more autonomous view of learning in an academic translation course. Educational Research, 44, 141 156.

Yüce, E. (2019). EPOSTL: Revisiting the roles of language teachers at a recently established ELTdepartment. International Online Journal of Education and Teaching (IOJET), 6(1). 234-243. http://www.iojet.org/index.php/IOJET/article/view/551

\section{Avrupa dil portfolyosu üniversite seviyesinde İngilizce öğrenmeyi teşvik ediyor $\mathrm{mu}$ ?}

\section{$\ddot{O} \mathbf{z}$}

Bu çalışma, 2016-2017 akademik yılında Bülent Ecevit Üniversitesi, Yabancı Diller Yüksekokulu'nda yabancı dil eğitimi gören öğrencilerin ve öğretmenlerinin Avrupa Dil Portfolyosu'na (ADP) olan algılarını incelemiştir. Bu çalışmada ADP kullanan öğrencilerle ve beş öğretmenle mülakat yapılmıştır ve ADP'ye karşı olan tutumları üzerinde bilgi almaya yönelik sorular yöneltilmiştir.

Çalışmanın nicel sonuçları ADP'nin sınıflarda öğretmenler ve öğrenciler tarafından doğru kullanımları şartıyla iyi bir öz-değerlendirme aracı olduğunu ve dil öğrenmeye karşı olumlu tutum geliştirmeye katkı sağladığı görülmüştür. Ayrıca, ADP hakkında yeterince bilgiye sahip olmaları koşulu ve sınıflarda doğru şekilde uygulanması koşuluyla öğrencilerin ADP'ye ve ADP ile çalışmaya olumlu yaklaştıkları görülmüştür. İlaveten, öğrenciler ve öğretmenler ADP'nin iyi bir öz-değerlendirme aracı olduğunu, fakat ADP Türkiye'de yeni bir araç olduğu için Bülent Ecevit Üniversitesi Yabancı Diller Yüksekokulu öğretmenlerinin ADP'yi müfredata ekleme ve doğru uygulanması konusuna desteğe ihtiyaçları olduğu görülmüştür. Ayıca, bu çalışma ADP'nin özdeğerlendirmeyi desteklemek ve öğrenci odaklı sınıflar oluşturmak için iyi bir araç olarak kullanılabileceğini göstermiştir.

Anahtar sözcükler: Öz değerlendirme, Avrupa Dil Portföyü (ADP), yaşam boyu yabancı dil öğrenimi, kültürlerarası yeterlilik, Ortak Avrupa Referans Çerçevesi (CEFR), yetişkin ADP

\section{AUTHOR BIODATA}

Assist. Prof. Dr. Burcu ŞENTÜRK holds a BA degree in English Language Teaching from Middle East Technical University (METU). She received an MA degree in English Language Teaching/TEFL from Bilkent University MA TEFL Program and her PhD in the Department of English Language Education at Hacettepe University. She is an Assistant Professor Dr. at Bartin University Foreign Language Education Department. She is also the Head of the same department and the director of the School of Foreign Languages at Bartın University. Her main teaching and research interests are educational linguistics, self-assessment, CEFR, language teacher education, English language teaching and language teaching methodology.

Prof. Dr. Ismail Hakki MIRICI, former Education Attaché of Turkish Consulate in Chicago, is the Dean of Ataturk Faculty of Education in Near East University in Nicosia, TRNC. He is also the Past President of the World Council for Curriculum and Instruction-WCCI(2011-2013), and the Founder of the WCCI Turkish Chapter. He has been lecturing at universities for about 35 years. He has about 20 books and more than 90 academic studies published in various academic journals or conference proceedings. He has participated in the steering committees of several national and international education projects. He is also the ELP National Contact Person of the Ministry of Education, Turkey in the Council of Europe. His main fields of studies are English Language Teaching, Teacher Training, and Curriculum and Instruction. 